\title{
The Effects of Mint Tea (Mentha spicata labiatae) Consumed During Pregnancy on Postnatal Morphometric Development
}

\section{Hamilelik Boyunca Nane (Mentha Spicata Labiatae) Çayı Tüketiminin Postnatal Morfometrik Gelişim Üzerine Etkileri}

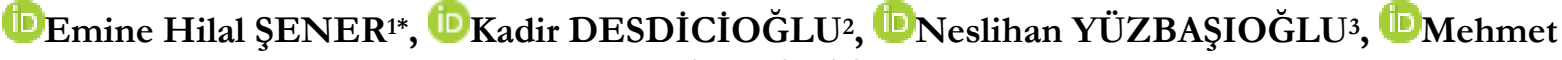
Ali MALAS 4

${ }^{1}$ Burdur Mehmet Akif Ersoy University, Faculty of Health Sciences, Department of Nursing, Burdur, Turkey ${ }^{2}$ Yıldırım Beyazıt University, Faculty of Medicine, Department of Anatomy, Ankara, Turkey

${ }^{3}$ Medipol University, Faculty of Medicine, Department of Anatomy, İstanbul, Turkey

${ }^{4}$ Katip Çelebi University, Faculty of Medicine, Department of Anatomy, İzmir, Turkey

\begin{abstract}
To investigate the effects of mint (Mentha spicata L.) tea consumed during pregnancy on prenatal maternal weight, length of pregnancy and morphometric development of pups in postnatal period. Twelve female $(7$ in mint tea group and 5 controls) and 6 male (used for mating) Wistar albino rats weighing 190-210 g were used in the study. Throughout the pregnancy, the mint tea group was given $4 \mathrm{ml}$ of mint (Mentha spicata L.) tea at the same time every day and the control group was given $4 \mathrm{ml}$ of commercial drinking water by gavage. Weights of pregnant rats in both groups were measured three times a week throughout the pregnancy. After the pups were born, morphometric growth parameters pertaining to the body, cranium, thorax and limbs were measured during newborn and lactation periods and adulthood. Pregnant rats in the MT group gained less weight during gestation than the control rats. Morphometric parameters were measured on a total of 66 pups born to rats in both groups (46 pups in the MT group; 20 pups in the control group and measurements of pups born to rats in the MT group were smaller than the control group $(\mathrm{p}<0.05)$. Morphometric parameters measured after six weeks showed a significant difference between females in the MT and control groups, with the females in the MT group having smaller measurements $(\mathrm{p}<0.05)$. There was no significant difference in morphometric parameters between males in the MT and control groups. Mint tea consumption during pregnancy has a negative effect on maternal weight gain and certain postnatal morphometric parameters, more prominently in female progenies. Therefore mint (Mentha spicata L.) tea consumption during pregnancy calls for caution.
\end{abstract}

Keywords: Mint (Mentha spicata L.) tea, developmental anatomy, morphometry, gestation, postnatal period.

Öz: Çalışmamızda, hamilelikte içilen nane (Mentha spicata L.) çayının prenatal ve postnatal dönemdeki morfometrik büyüme üzerine olan etkilerinin araştırılması amaçlandı. Çalışmaya, ağırlıkları 190 ve 210 gram arasında olan toplam 12 dişi Wistar albino rat (7 çalışma, 5 kontrol) alınd. Hamilelik süresi boyunca deney grubuna her gün aynı saatte günlük $4 \mathrm{cc}$ nane çayı ve kontrol grubuna da $4 \mathrm{cc}$ ticari içme suyu gavaj yöntemi ile verildi. Gruplarındaki hamile ratların ağırlıkları, hamilelik boyunca gün aşırı ölçüldü. Hamilelik sonunda, ratların hamilelik süreleri ve yavru sayıları tespit edildi. Total gövde, kranium, toraks ve ekstremite ile ilgili morfometrik büyüme parametreleri, her bir yavru için yenidoğan-erişkin dönemleri boyunca ölçüldü. Deney grubundaki hamile ratların hamilelikleri boyunca kontrol grubuna göre daha az kilo aldıkları tespit edildi. Her iki gruptan elde edilen 66 yavruya ait (deney 46; kontrol 20) morfometrik parametrelerin ölçümünde, kontrol grubunda deney grubunun daha düşük değerlere sahip olduğu bulundu $(\mathrm{p}<0,05)$. 6. haftadan sonra cinslere göre bakılan parametrelerde ise, deney grubundaki dişilerin morfometrik parametrelerinin kontrol grubu dişilerine göre daha düşük olduğu $(p<0,05)$ ve deney ve kontrol grubunda yer alan erkekler arasındaki morfometrik parametreler arasında ise fark olmadığı belirlendi. Hamilelikte nane çayı tüketiminin maternal kilo alımını ve doğum sonrası dönemde ise yavruların morfometrik parametrelerini özellikle dişi yavrular üzerinde daha belirgin olmak üzere negatif yönde etkilediği ve bu nedenle hamilelik boyunca nane (Mentha spicata L.) çayının kullanımına dikkat edilmesi gerektiği sonucuna varıldı.

Anahtar Kelimeler: Nane (Mentha spicata L.) çayı, gelişim anatomisi, morfometri, hamilelik dönemi, postnatal dönem.

${ }^{*}$ Corresponding author : Emine Hilal ŞENER e-mail : hilalsener@mehmetakif.edu.tr

Geliş tarihi / Received : 22.03.2019

Kabul tarihi / Accepted: 17.05.2019 


\section{Introduction}

Mint (Mentha piperita labiatae and Mentha spicata labiatae) is an aromatic herb that has been used for therapeutic purposes or simply as a drink. Also mint has gas expelling, cramp relieving, antiemetic, antipyretic, analgesic, nervous system boosting, antiseptic, antibacterial (menthol, antiseptic) and antifungal effects (Saleem et al., 2000, Akdoğan et al.,2004, Güney et al., 2006).

A study carried out in North America revealed that herbal teas are used in the first trimester to alleviate nausea and vomiting (Westfall, 2004). They are also used frequently to relieve thirst, to benefit from its soothing properties and to increase the amount of milk production during lactation (Ernst, 2002, Westfall, 2004). It has been argued that more data is needed with regard to the safety of using herbal teas during pregnancy (Westfall, 2004).

It has been reported that $M$. spicata $L$. causes important histopathological and biochemical changes in kidneys (Akdoğan et al., 2003). Another study argued that essential lipids extracted from $M$. piperita L. and M. spicata L. had the potential to be used as an antibacterial agent by inhibiting the development of pathogens (Helicobacter pylori and Staphylococcus aureus) (Imai et al., 2001). M. spicata L. was shown to have a dose-dependent protective effect on cutaneous oxidative stress, toxicity and hyperproliferative effects induced by benzoly peroxide (Westfall, 2004).

Serious medical conditions related to the overuse of herbal teas are usually understated. In fact, active ingredients of certain herbal teas have the potential to induce abortion, increase the risk of gestational hemorrhage and increase uterine contractions, resulting in premature birth. Excessive use of certain herbal products has been linked to malformations, miscarriage and stillbirths (Ernst, 2002). It should be noted that M. spicata L., when consumed in large quantities, has nephrotoxic effects and causes apoptosis (Güney et al., 2006).

Balanced secretion of hormones during the fetal period affects intrauterine and postnatal development. It is known that imbalance of prenatal testosterone secretion affects the development of genitalia and descendes testes (Zambrano et al., 2005). It has been reported that M. spicata $L$. tea consumption has detrimental effects on reproductive system, causes degenerative changes in the germinal epithelium and interrupts spermatogenesis. It has been shown that M. spicata Lincreases LH and FSH levels while decreasing testosterone level significantly (Akdoğan et al., 2004).

Food and liquids taken during pregnancy have an impact on prenatal and postnatal morphometric development (Villar et al., 1986, Osgerby et al., 2002, Chen et al., 2004). Therefore, we hypothesized that consumption of M. spicata L. tea during pregnancy may have an effect on prenatal and postnatal growth. A literature research did not reveal any studies on the effects of gestational $M$. spicata $L$. tea consumption on prenatal and postnatal morphometric growth.

In this study, we aimed to investigate the effects of M. spicata $L$. tea consumed during pregnancy on prenatal maternal weight, length of pregnancy, and postnatal morphometric growth.

\section{Material and Methods}

The study carried out on a total 18 sexually mature Wistar albino rats, (12 females (14 - 16 weeks old, weighing $190-210 \mathrm{~g}$ ) and 6 males used for mating), were obtained from the Experimental Animals Laboratory of Süleyman Demirel University. Ethics approval was given by Ethics Board of Faculty of Medicine, Süleyman Demirel University prior to the commencement of the study. The rats selected for the study were placed in the experiment environment for adaptation a week before mating. All rats were maintained on a 12h: $12 \mathrm{~h} \mathrm{light/dark} \mathrm{(am.08.00,} \mathrm{pm.} \mathrm{08.00)} \mathrm{cycle,} \mathrm{in}$ an air-conditioned room with controlled temperature of $24 \pm 2^{\circ} \mathrm{C}$ and had free access to food and water.

Rats were randomly divided into two groups, namely experiment (mint tea) (MT, n:7) and 


\section{doi: $10.24998 /$ maeusabed.543364}

control groups (n:5). Rats were placed in cages, each cage containing one male and two female rats, and they were left for 24 hours for mating. At the end of 24 hours females and males were separated. The day female and male rats were separated was denoted "E1" (Embryonic day 1). Pregnancies of female rats were controlled by vaginal smears. Four rats in the MT and two rats in the control group were become pregnant. Pregnant rats were haused in cages, with two rats in each cage.

During gestation, control group was given commercial drinking water (AYSU water; $\mathrm{Ca}^{2+} 27$ $\mathrm{mg} / \mathrm{L}, \mathrm{F}^{-} 0.06 \mathrm{mg} / \mathrm{L}, \mathrm{Mg}^{2+} 4.60 \mathrm{mg} / \mathrm{L}^{2} \mathrm{HCO}_{3}{ }^{-}$ $179 \mathrm{mg} / \mathrm{L}, \mathrm{Na}^{+} 2.3 \mathrm{mg} / \mathrm{L}^{-} \mathrm{Cl}^{-} 7.10$ and $\mathrm{PH} 7.66$ ) while rats in the MT group were given, $4 \mathrm{ml}$ of mint $(20 \mathrm{~g} / 1$, Mentha spicata L.) as described in previous studies, by gavage everyday at the same time $(8: 00 \mathrm{am})$. The herbal teas were prepared by pouring $5 \mathrm{~g}$ of the dried leaves in $250 \mathrm{~mL}$ (1 cup) of boiling water and let to steep for 5 to 10 minutes (Akdoğan et al., 2004). Mint tea was prepared daily. All of the rats had ad libitum access to food and water throughout the study.

During gestation, pregnant rats in the MT and control groups were weighed every other day until birth to determine the amount of weight gain during pregnancy. Each pregnant rat was placed in a separate cage on $18^{\text {th }}$ day of gestation. Length of gestation was determined in the MT and control groups and any deviation from normal (21 days) duration was noted (premature and postmature birth). The number of newborn pups, size and general features in the MT and control groups were also recorded at the end of pregnancy. Sucking/rooting reflex, movement, color, anal and urethral openings and presence or absence of a malformation was assessed on newborn pups (Baiy et al., 2004, Zhang et al., 2008). Further, eye and ear opening times, tooth eruption time and the time of descent of the testes were also recorded (Balbani et al., 2008, Fun et al., 2008).

Morphometric growth parameters from the body, thorax, cranium and limbs were measured in each pup born to rats in the MT and control groups throughout the newborn and lactation periods and adulthood, on day 0 (within the first 24 hours of birth) and weeks 1, 2, 3, 4, 5, 6, 10 and 12. We used the same methods and standard anthropometric points that were used in previous animal studies to measure the morphometric growth parameters (Wells, 1964, Smith et al., 1993, Moore and Persoud, 2002, York et al., 2004, Jamerson, 2004, Lawson and Luderer, 2004). Morphometric reference points were used for the parameters that were measured in the present study but not measured before (Sharp and La Regina, 1998, Malas et al., 2006, Tyl et al., 2007). All measurements were performed as described below using plastic and metal rulers, measuring tape and silk suture thread.

(a) Pup weight: Measured using DENSI DS-05 electronic scale.

(b) Head circumference (HC): The distance around the widest part of the skull passing from the glabella of the frontal bone, parietal tuber, and posterior-most point of the occipital bone.

(c) Bi-parietal diameter (BPD): Transverse distance between the parietal tubers.

(d) Skull length: Sagittal distance between glabella and the posterior-most point of the occipital bone.

(e) Face length: Distance between glabella and the anterior-most point of the mandible.

(f) Bi-orbital diameter: Transverse distance between the lateral rims of the orbits.

(g) Thorax circumference: Distance measured at the widest part of the thorax.

(h) Thorax width: Transverse distance between two vertical planes passing through the outermost points of the thorax.

(i) Crown-rump length (CRL): Distance between the vertex and the point where the tail started.

(j) Naso-anal length: The distance between the tip of the nose and the midpoint of the anus.

(k) Forearm length: Distance between the midpoint of the elbow joint and the tip of the longest digit on forelimb.

(l) Leg length: Distance between the midpoint of the knee joint and the tip of the longest digit on hindlimb.

(m) Bi-acetabular distance: Transverse distance between the greater trochanters.

(n) Ano-genital distance: Distance between the midpoint of the anus and the external urethral orifice. 


\section{doi: $10.24998 /$ maeusabed.543364}

Data obtained was assessed separately for the newborn, lactation and puberty/adulthood periods:

a) Parameters pertaining to newborn period (day 0)

b) Parameters pertaining to Lactation period (days 7, 14 and 21)

c) Parameters pertaining to puberty and adulthood (Weeks 4, 5, 6, 10 and 12).

Further parameters were measured in male and female pups sepatately after week 6 .

Mean weight gained during pregnancy by rats in the MT and control groups and arithmetic means of all parameters in MT and control pups and standard deviations associated with these means were calculated for each week. Further, means and standart deviations of sex dependent parameters were started to determine after 6th week and arithmetic means and standart deviations of all parameters with respect to gender were also determine at weeks 6,10 and 12. Student's $t$-test and non-parametric Mann-Whitney $U$ test was used to compare the parameters between the MT and control groups. The relations between age and all parameters obtained during newborn, lactation periods and adulthood were tested by Pearson's correlation test. The level of statistical significance was set at 0.05 .

\section{Results}

Four rats in the MT, two rats in the control group became pregnant. Maternal weight of rats in the MT and control groups was measured every other day until the day of birth. Increase in maternal weight in the MT group during gestation was less than the control group (Figure 1; total weight gain: $90.5 \mathrm{~g}$ in the MT group, $97.75 \mathrm{~g}$ in the control group). All animals in the MT and control groups completed the normal course of pregnancy (21 days).

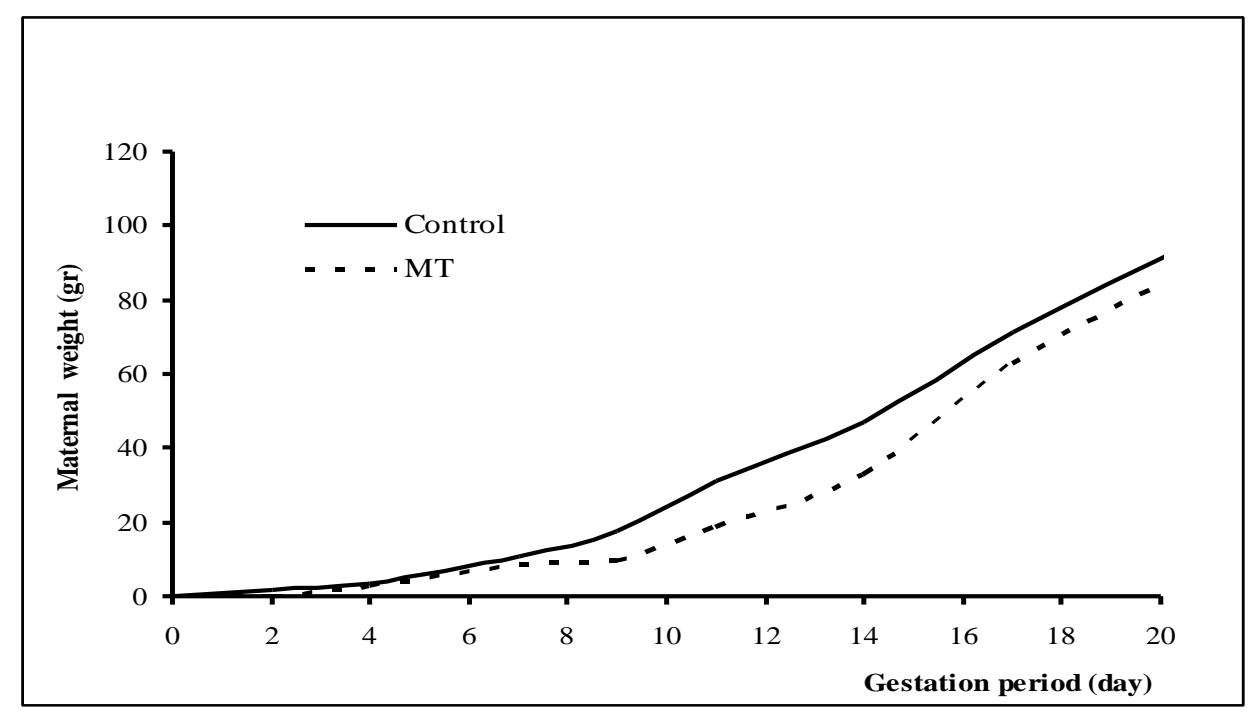

Figure 1. Changes in mean maternal weight gained by pregnanat rats in the mint tea (MT) and control groups throughout the pregnancy. 
MAKU J. Health Sci. Inst. 2019, 7(1): 29-40.

doi: $10.24998 /$ maeusabed. 543364

Table 1: Arithmetic means (g, $\mathrm{mm}$ ) and standard deviations of weight and general morphometric parameters of mint tea (MT) and control pubs measured between newborn, lactation and adulthood.

\begin{tabular}{|c|c|c|c|c|c|c|c|c|c|c|c|c|}
\hline \multirow[b]{3}{*}{$\begin{array}{l}\text { Group } \\
(\mathbf{N})\end{array}$} & \multicolumn{12}{|c|}{ General parameters } \\
\hline & \multicolumn{2}{|c|}{ Weight (g) } & \multicolumn{2}{|c|}{ Crown-rump length (CRL) } & \multicolumn{2}{|c|}{ Thorax circumference } & \multicolumn{2}{|c|}{ Thorax width } & \multicolumn{2}{|c|}{ Naso-anal length } & \multicolumn{2}{|c|}{ Ano-genital distance } \\
\hline & MT (46) & Control (20) & MT (46) & Control (20) & MT (46) & Control (20) & MT (46) & $\begin{array}{c}\text { Control } \\
(20)\end{array}$ & MT (46) & Control (20) & MT (46) & $\begin{array}{c}\text { Control } \\
\text { (20) }\end{array}$ \\
\hline \multicolumn{13}{|l|}{ Newborn } \\
\hline First day & $7,41 \pm 1,24$ & $6,50 \pm 0,41$ & $41,76 \pm 1,15$ & $43,30 \pm 1,78$ & $40,36 \pm 1,23$ & $41,15 \pm 0,74$ & $14,95 \pm 1,24$ & $16,20 \pm 1,23$ & $43,04 \pm 1,29$ & $44,40 \pm 1,93$ & $2,07 \pm 0,29$ & $2,00 \pm 0,00$ \\
\hline \multicolumn{13}{|l|}{ Lactation } \\
\hline 1st week & $11,65 \pm 2,16$ & $11,85 \pm 0,79$ & $54,04 \pm 3,34$ & $55,70 \pm 1,65$ & $47,52 \pm 2,81$ & $49,20 \pm 2,16$ & $16,82 \pm 1,45$ & $17,80 \pm 1,69$ & $56,23 \pm 3,49$ & $57,90 \pm 1,44$ & $3,08 \pm 0,35$ & $3,30 \pm 0,47$ \\
\hline 2nd week & $16,95 \pm 3,26$ & $20,65 \pm 1,77$ & $58,02 \pm 8,43$ & $62,60 \pm 1,98$ & $54,08 \pm 2,75$ & $60,75 \pm 2,84$ & $20,71 \pm 2,10$ & $22,35 \pm 1,56$ & $65,19 \pm 4,74$ & $70,90 \pm 2,65$ & $4,73 \pm 1,23$ & $5,60 \pm 0,99$ \\
\hline 3rd week & $23,40 \pm 4,68$ & $28,42 \pm 3,60$ & $73,04 \pm 6,68$ & $79,00 \pm 4,96$ & $61,26 \pm 6,54$ & $67,10 \pm 6,58$ & $26,73 \pm 3,07$ & $30,00 \pm 3,06$ & $78,73 \pm 7,29$ & $85,35 \pm 4,63$ & $7,58 \pm 2,07$ & $9,40 \pm 2,37$ \\
\hline \multicolumn{13}{|l|}{ Adulthood } \\
\hline 4th week & $40,14 \pm 5,80$ & $45,90 \pm 6,12$ & $88,58 \pm 5,44$ & $93,25 \pm 3,12$ & $74,30 \pm 5,54$ & $78,25 \pm 4,94$ & $32,69 \pm 2,35$ & $37,10 \pm 3,11$ & $97,45 \pm 5,80$ & $104,30 \pm 4,53$ & $11,39 \pm 2,30$ & $12,90 \pm 1,61$ \\
\hline 6th week & $81,20 \pm 19,40$ & $91,85 \pm 13,13$ & $112,80 \pm 8,94$ & $115,25 \pm 24,52$ & $97,47 \pm 8,52$ & $104,05 \pm 6,10$ & $41,39 \pm 3,05$ & $43,50 \pm 3,70$ & $125,91 \pm 11,10$ & $136,15 \pm 4,88$ & $13,67 \pm 4,25$ & $15,55 \pm 3,76$ \\
\hline 10th week & $115,96 \pm 43,26$ & $148,50 \pm 29,61$ & $127,32 \pm 15,55$ & $136,15 \pm 7,32$ & $109,06 \pm 9,80$ & $125,50 \pm 12,73$ & $41,43 \pm 5,50$ & $45,30 \pm 2,57$ & $142,30 \pm 17,41$ & $156,55 \pm 10,36$ & $14,55 \pm 5,14$ & $16,65 \pm 4,55$ \\
\hline 12th week & $149,15 \pm 46,88$ & $191,70 \pm 31,43$ & $139,80 \pm 10,86$ & $145,40 \pm 9,29$ & $121,04 \pm 13,37$ & $129,40 \pm 9,56$ & $42,13 \pm 4,31$ & $46,50 \pm 2,91$ & $148,58 \pm 14,84$ & $161,65 \pm 9,67$ & $16,63 \pm 5,63$ & $18,90 \pm 6,22$ \\
\hline
\end{tabular}

$\mathrm{P}<0,05$; Differences in all parameters and in all periods between in the MT and control groups. 
MAKU J. Health Sci. Inst. 2019, 7(1): 29-40.

doi: $10.24998 /$ maeusabed.543364

Table 2: Arithmetic means ( $\mathrm{mm}$ ) and standard deviations of morphometric parameters pertaining to the cranium of mint tea (MT) and control pubs measured between newborn, lactation and adulthood.

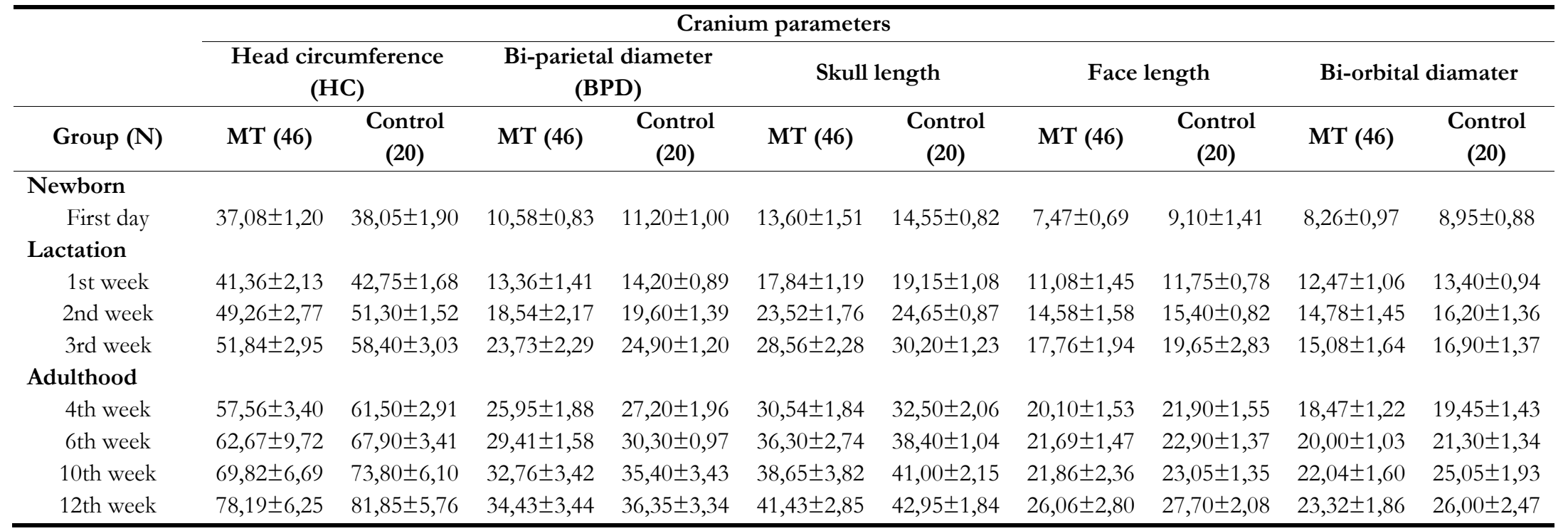

$\mathrm{P}<0,05$; Differences in all parameters and in all periods between in the MT and control groups. 


\section{doi: $10.24998 /$ maeusabed.543364}

Four rats delivered forty six pups $(15 \mathrm{M}, 31 \mathrm{~F})$ and other two rats had twenty pups (11 M, $9 \mathrm{~F}$ ) pregnant rats in the MT and control groups, respectively. There were no abnormalities or pathologies in sucking/rooting reflex, motor movements, color, anal and urethral openings, or eye and ear opening in any of the pups in the MT and control groups. Birth complications such as spontaneous abortion were not observed in either group.

Morphometric growth parameters pertaining to total body, cranium, thorax and limbs of pups in MT and control groups were measured from the day of birth (day 0 ) until week 12 , separate for the newborn and lactation periods and adulthood. Means and standard deviations of all parameters with respect to weeks obtained from the MT and control groups are presented in Tables 1,2,3.

Sex of pups could be determined at the fist postnatal week by anogenital distance. All pubs were lived with their mother during lactation. At the end of the postnatal $4^{\text {th }}$ week (end of the lactation) male and female pubs were separated different cage because of mating. Table 2 shows the arithmetic means and standard deviations of all parameters in both groups between weeks 6 and 12 with respect to males and females. There were significant differences between the MT and control groups in all parameters and in all periods, with smaller measurements in the MT group $(p<0.05$, Tables 1,2,3). Parameters measured between weeks 6 and 12 were compared between rats of same sex in MT and control groups (MT male- control male comparisons, MT femalecontrol female comparisons). There were significant differences in $7 \%$ of the parameters (ano-genital distance at week 6 and bi-orbital diameter at weeks 10 and 12) between males whereas there were significant differences in $95 \%$ of the parameters (all parameters except ano-genital distance at weeks 10 and 12) between females $(p<0.05$, Table 4$)$.

Comparison of sexes within groups (males to females) revealed, both in MT and control groups, significant difference in ano-genital distance, with males having larger ano-genital distance $(\mathrm{p}<0.05$, Table 4). There were significant sex differences in $88 \%$ and $33 \%$ of the parameters measured in the MT (all parameters except head circumference and face length at week 6 and bi-orbital diameter at weeks 6, 10 and 12) and control groups, respectively, with measurements in males being greater $(\mathrm{p}<0.05$, Table 4). All parameters measured during newborn and lactation periods and adulthood, both in the MT and control groups, correlated positively with age $(\mathrm{p}<0.001)$

Table 3: Arithmetic means ( $\mathrm{mm}$ ) and standard deviations of morphometric parameters pertaining to the limbs of mint tea (MT) and control pubs measured between newborn, lactation and adulthood.

\begin{tabular}{ccccccc}
\hline \multicolumn{5}{c}{ Limb parameters } \\
\cline { 2 - 6 } Group (N) & MT (46) & Control (20) & MT (46) & $\begin{array}{c}\text { Control } \\
\text { (20) }\end{array}$ & MT (46) & Control (20) \\
\hline $\begin{array}{c}\text { Newborn } \\
\text { First day }\end{array}$ & $11,28 \pm 1,25$ & $12,65 \pm 1,59$ & $6,78 \pm 0,98$ & $7,55 \pm 0,94$ & $16,69 \pm 0,59$ & $17,35 \pm 0,48$ \\
Lactation & & & & & & \\
1st week & $16,08 \pm 1,36$ & $17,00 \pm 1,07$ & $11,04 \pm 1,34$ & $11,95 \pm 1,09$ & $17,76 \pm 1,64$ & $18,50 \pm 1,05$ \\
2nd week & $23,36 \pm 2,35$ & $24,85 \pm 1,34$ & $17,89 \pm 2,39$ & $19,40 \pm 1,04$ & $23,13 \pm 2,39$ & $24,35 \pm 1,34$ \\
3rd week & $29,04 \pm 2,59$ & $30,85 \pm 1,95$ & $23,76 \pm 2,42$ & $26,40 \pm 2,11$ & $30,19 \pm 3,48$ & $32,25 \pm 2,86$ \\
Adulthood & & & & & & \\
4th week & $33,47 \pm 1,79$ & $34,95 \pm 1,46$ & $28,89 \pm 2,00$ & $30,75 \pm 1,74$ & $35,08 \pm 2,73$ & $39,60 \pm 3,33$ \\
6th week & $39,06 \pm 2,96$ & $41,50 \pm 1,93$ & $35,06 \pm 1,66$ & $36,15 \pm 2,05$ & $45,45 \pm 2,79$ & $49,50 \pm 4,04$ \\
10th week & $40,86 \pm 3,23$ & $44,35 \pm 2,05$ & $37,47 \pm 2,76$ & $40,50 \pm 1,19$ & $49,10 \pm 6,77$ & $55,35 \pm 6,53$ \\
12th week & $44,71 \pm 3,32$ & $47,80 \pm 3,05$ & $38,41 \pm 3,27$ & $42,60 \pm 2,81$ & $50,89 \pm 5,46$ & $56,35 \pm 4,35$ \\
\hline
\end{tabular}

$\mathrm{P}<0,05$; Differences in all parameters and in all periods between in the MT and control groups. 
MAKU J. Health Sci. Inst. 2019, 7(1): 29-40.

doi: $10.24998 /$ maeusabed. 543364

Table 4: Aritmetic means $(\mathrm{mm})$ and standart deviations of morphometric parameters pertaining to the general, carnium and limbs of male and female pubs in the MT and control groups measured at weeks 6,10 and 12 .

\begin{tabular}{|c|c|c|c|c|c|c|c|c|c|c|c|c|}
\hline \multirow{3}{*}{$\begin{array}{l}\text { Groups } \\
\text { Genders (n) }\end{array}$} & \multicolumn{4}{|c|}{ 6th week } & \multicolumn{4}{|c|}{ 10th week } & \multicolumn{4}{|c|}{ 12th week } \\
\hline & \multicolumn{2}{|c|}{ MT } & \multicolumn{2}{|c|}{ Control } & \multicolumn{2}{|c|}{ MT } & \multicolumn{2}{|c|}{ Control } & \multicolumn{2}{|c|}{ MT } & \multicolumn{2}{|c|}{ Control } \\
\hline & Male (15) & Female (31) & Male (15) & Female (31) & Male (15) & Female (31) & Male (15) & Female (31) & Male (15) & Female (31) & Male (15) & Female (31) \\
\hline Weight & $100,23 \pm 18,28$ & $72,00 \pm 11,84$ & $93,27 \pm 17,05$ & $90,11 \pm 6,31$ & $169,30 \pm 36,22$ & $90,16 \pm 9,19$ & $152,72 \pm 38,92$ & $143,33 \pm 11,58$ & $198,06 \pm 46,68$ & $125,48 \pm 22,48$ & $203,27 \pm 34,51$ & $177,55 \pm 21,16$ \\
\hline Head circumference & $62,33 \pm 16,32^{\mathrm{c}}$ & $62,83 \pm 4,17 \mathrm{c}$ & $67,90 \pm 4,22^{c}$ & $67,88 \pm 2,31^{c}$ & $74,33 \pm 9,23$ & $67,64 \pm 3,52$ & $73,27 \pm 8,00$ & $74,44 \pm 2,74$ & $85,20 \pm 5,19$ & $74,80 \pm 3,10$ & $84,09 \pm 6,70$ & $79,11 \pm 2,71$ \\
\hline Bi-parietal diamater & $30,33 \pm 1,75$ & $28,96 \pm 1,30$ & $30,00 \pm 0,89$ & $30,66 \pm 1,00$ & $35,26 \pm 4,28$ & $31,54 \pm 2,07$ & $35,00 \pm 4,19$ & $35,88 \pm 2,36$ & $38,06 \pm 2,63$ & $32,67 \pm 2,18$ & $36,90 \pm 4,27$ & $35,66 \pm 1,65$ \\
\hline Skull length & $38,80 \pm 1,93$ & $35,09 \pm 2,22$ & $38,90 \pm 1,04$ & $37,77 \pm 0,66$ & $41,93 \pm 3,80$ & $37,06 \pm 2,68$ & $41,18 \pm 2,82$ & $40,77 \pm 0,97$ & $44,00 \pm 2,80$ & $40,19 \pm 1,62$ & $43,27 \pm 2,10$ & $42,55 \pm 1,50$ \\
\hline Face length & $22,13 \pm 1,50^{c}$ & $21,48 \pm 1,43^{c}$ & $22,90 \pm 1,37 \mathrm{c}$ & $22,88 \pm 1,45^{c}$ & $23,86 \pm 1,92$ & $20,90 \pm 1,92$ & $23,36 \pm 1,68$ & $22,66 \pm 0,70$ & $28,93 \pm 1,94$ & $24,64 \pm 1,97$ & $28,18 \pm 2,44$ & $27,11 \pm 1,45$ \\
\hline Thorax circumference & $102,13 \pm 5,69$ & $95,22 \pm 8,81$ & $104,18 \pm 7,54$ & $103,88 \pm 4,16$ & $119,60 \pm 9,11$ & $103,96 \pm 5,04$ & $123,54 \pm 13,98$ & $127,88 \pm 11,36$ & $135,13 \pm 12,46$ & $114,22 \pm 6,97$ & $132,54 \pm 10,82$ & $125,55 \pm 6,34$ \\
\hline Thorax width & $43,00 \pm 3,44$ & $40,61 \pm 2,56$ & $41,72 \pm 2,49$ & $45,66 \pm 3,90$ & $47,80 \pm 4,75$ & $38,35 \pm 2,21$ & $46,09 \pm 3,04$ & $44,33 \pm 1,50$ & $46,26 \pm 2,98$ & $40,12 \pm 3,32$ & $48,27 \pm 2,76$ & $44,33 \pm 1,00$ \\
\hline Crown-rump length & $121,00 \pm 6,86$ & $108,83 \pm 6,93$ & $109,09 \pm 31,68$ & $122,77 \pm 7,54$ & $143,86 \pm 14,99$ & $119,32 \pm 7,42$ & $140,36 \pm 6,91$ & $131,00 \pm 3,64$ & $150,40 \pm 8,00$ & $134,67 \pm 7,99$ & $148,90 \pm 9,22$ & $141,11 \pm 7,81$ \\
\hline Naso-anal length & $136,33 \pm 9,34$ & $120,87 \pm 7,96$ & $135,45 \pm 5,68$ & $137,00 \pm 3,84$ & $161,40 \pm 15,59$ & $133,06 \pm 8,42$ & $159,27 \pm 12,86$ & $153,22 \pm 5,04$ & $163,33 \pm 10,63$ & $141,45 \pm 10,78$ & $166,90 \pm 9,23$ & $155,22 \pm 5,58$ \\
\hline Forearm length & $40,53 \pm 2,03$ & $38,35 \pm 3,10$ & $40,54 \pm 1,03$ & $42,66 \pm 2,17$ & $44,60 \pm 2,22$ & $39,06 \pm 1,75$ & $44,72 \pm 2,61$ & $43,88 \pm 1,05$ & $47,33 \pm 2,43$ & $43,45 \pm 2,95$ & $49,09 \pm 2,38$ & $46,22 \pm 3,15$ \\
\hline Leg length & $35,66 \pm 1,75$ & $34,77 \pm 1,56$ & $35,09 \pm 0,30$ & $37,44 \pm 2,55$ & $40,60 \pm 1,45$ & $35,96 \pm 1,79$ & $40,45 \pm 1,36$ & $40,55 \pm 1,01$ & $41,46 \pm 2,97$ & $36,93 \pm 2,25$ & $43,90 \pm 2,66$ & $41,00 \pm 2,17$ \\
\hline Bi-acetabular distance & $47,20 \pm 2,54$ & $44,61 \pm 2,53$ & $51,81 \pm 3,54$ & $46,66 \pm 2,59$ & $56,73 \pm 5,62$ & $45,41 \pm 3,30$ & $55,18 \pm 5,75$ & $55,55 \pm 7,73$ & $55,33 \pm 4,41$ & $48,74 \pm 4,58$ & $58,00 \pm 5,05$ & $54,33 \pm 2,17$ \\
\hline
\end{tabular}

a $\mathrm{P}<0,05$; Difference between rats of same gender (male-male) in MT and control groups (except ano-genital distance at week 6 and bi-orbital diamater at weeks 10 and 12).

b $\mathrm{P}<0,05$; Difference between rats of same gender (female-female) in MT and control groups (except ano-genital distance at weeks 10 and 12 )

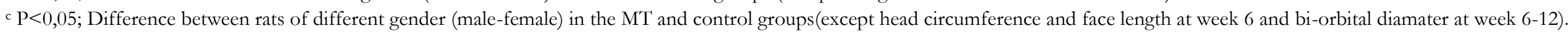




\section{Discussion}

Numerous research reported relationships between nutrition during gestation and brain development, intra-uterine death, premature birth and birth weight (Atasu et al., 2000, Feron et al., 2005). Various types of herbal teas are used during gestation (Saleem et al., 2000, Westfall, 2004, Guney et al., 2006). It has been argued that herbal teas, food and drinks consumed during gestation have effects on postnatal morphometric development (Villar et al., 1986, Ernst, 2002; Osgerby et al., 2002, Chen et al., 2004). However, there are no studies in the literature that adressed adverse effect of gestational consumption of mint tea on postnatal morphometric growth.

Many factors affect maternal weight during gestation. Maternal weight gain has a direct impact on the development of offspring. In previous study, maternal weight gain or loss during gestation has been effects on prenatal and postnatal development of offspring (Calmihael and Abrams, 1997, Shapiro et al., 2000, Dipietro et al., 2003, Sekiya et al., 2007). Weight gain during gestation has been shown to have an effect on fetal growth, birth weight as well as the length of gestation. Low weight gain at the beginning of gestation is closely related to preterm birth (Sekiya et al., 2007). Incidence of preterm birth increases when weekly weight gain during gestation is low ( $\leq 400 \mathrm{~g}$ ) (Shapiro et al., 2000).

A literature search did not reveal any study on gestational consumption of herbal teas, especially M. spicata L. tea. However, Guney et al. (2006) showed that $M$. spicata $L$. tea given to adult rats did not affect weight but had toxic effects on metabolism. We found that weight gained by pregnant rats given $M$. spicata $L$. tea during gestation was less than the control group (MT: 90.50 g; control: 97.75 g; Figure 1). Guney et al. (2006) attributed the histopathological and histochemical changes they observed in adults rats given mint tea to the toxic effects of M. spicata $L$. tea. In our study decrease weight gain during gestation observed in rats in the MT group may also be attributed to the toxic effects of $M$. spicata L. However, other factors may be held accountable for this finding (Joshi et al., 2003, Torres and Nowson, 2007). We did not find any difference in the length of gestation between MT and control groups. Gestation lasted 21 days in all rats in either group. In our study we determined that $M$. spicata $L$. tea consumption during gestation does not have an effect on the length of gestation.

Studies showed that certain nutritional habits caused prenatal growth retardation and these effects continued in the postnatal period (Joshi et al., 2003, Chen et al., 2004, York et al., 2004). These studies reported postnatal macroscopic findings of low birth weight, small stature, structural malformations and growth retardation among offspring (Galler et al., 1994, Joshi et al., 2003, Chen et al., 2004, Osgerby et al., 2002, York et al., 2004). It has also been emphasized that these results also affect the postnatal development of the offspring (York et al., 2004, Mahajan et al., 2004). We found that sucking/rooting reflex, movements, color, anal and urethral openings, eye and ear openings were normal in all newborn pups in the MT and control groups. As stated earlier, there are no studies on gestational use of herbal teas, especially M. spicata L. tea.

However, experimental studies conducted for maternal protein malnutrition especially in the early stages of gestation showed fetal losses and malformations (Galler et al., 1994). Further, postnatal morphometric growth retardation has been described in studies on nutrition during gestation (Osgerby et al., 2002, York et al., 2004).

Postnatal growth parameters pertaining to body, thorax, cranium and limbs of pups in MT and control groups were measured in newborn and lactation periods and adulthood between day 0 and week 12 (Tables 1,2,3). Comparison of all parameters obtained in MT and control groups showed that growth parameters in the MT group were significantly smaller than the control group $(p<0.05$, Tables $1,2,3)$. One thing of note was that the birth weight of pups in MT group on day 0 was greater than the control group. But this difference gradually decreased and was reversed in favor of the control group on day 7 and the increase in weight gained by pups in MT group was less than that in the control group $(\mathrm{p}<0.05$, Table 1$)$.

Considering morphometric features of male rats generally grater than females so pubs were classified to sex when compairing. We investigated whether there were sex differences in the 


\section{doi: $10.24998 /$ maeusabed.543364}

parameters obtained at weeks 6,10 and 12 between MT and control groups. Parameters obtained from rats of same sex were compared between groups (male-male, female-female) and there were significant differences in $7 \%$ of the parameters measured in male pups from both MT and control groups while significant differences appeared in $95 \%$ of the parameters measured in female pups from MT and control groups. All parameters were greater in the control group $(p<0.05$, Table 4). Comparison of parameters between males and females in the same group revealed that there were significant sex differences in $88 \%$ of the parameters measured in the MT group, with measurements of males being greater than females. On the other hand, in the control group 33\% of the parameters were greater in males $(\mathrm{p}<0.05$, Table 4$)$.

When we looked at the correlations between age and all parameters measured at weeks 6, 10 and 12, separate for each sex, we found high correlations in males and females in the control group and males in the MT group (r: 0.99 - 0.75). Parameters in females of MT group correlated weakly or moderately with age (r: 0.01-0.49). These results led us to conclude that gestational M. spicata $L$. consumption affects postnatal morphometric development of female pups more than male pups.

Previous studies reported that M. spicata $L$. tea given to adult male rats had adverse effects on reproductive system, induced degenerative changes in germinal epithelium, and stopped spermatogenesis (Akdoğan et al., 2004). M. spicata $L$, with known adverse effects especially on the endocrine system, increases LH and FSH levels while significantly decreasing plasma testosterone level (Akdoğan et al., 2004). Excessive amounts of mint tea given to females induce toxic (nephrotoxic) effects (Guney et al., 2006). Maternal protein malnutrition during gestation has been reported to delay sexual maturation in males and reduce testosterone and $\mathrm{LH}$ concentrations in early postnatal period. Delay in the testicular descent and reductions in testicular weight, fertility and sperm count in late postnatal period have also been reported (Zambrano et al., 2005). The present study reported that $M$. spicata $L$. tea consumed during gestation had adverse impact on morphological development of pups and this impact was more pronounced on female pups. These adverse effects of $M$. spicata $L$ tea consumed by mothers during gestation on postnatal pups is thought to be due to toxic effects especially on the endocrine system, as the results of a previous study on adult rats showed (Guney et al., 2006).

In conclusion, there is a shortfall of studies on the postnatal effects of herbal teas consumed during gestation. In that sense, this is a pioneer study exploring the prenatal and postnatal effects of $M$. spicata $L$. tea consumed during gestation on morphometric growth. Based on the results of the present study, we can say that $M$. spicata $L$. tea consumed during gestation has adverse effects on postnatal development, especially of females. Number of animals in experiment groups stayed because of rats became pregnant. Therefore, further studies with more animals are required to demonstrate the effects of gestational use of mint teas on postnatal development and differential effects on sexes. Also other herbal teas might have adverse effects on postnatal development.

\section{References}

Akdogan, M., Kılınç, I., Oncu, M., Karaöz E, Delibaş N., 2003. Investigation of biochemical and histopathological effects of mentha piperita L. and mentha spicata L. on kidney tissue in rats. Human \& Experimental Toxicology 22, 213-9.

Akdogan, M., Ozguner, M., Koçak, A., Öncü M., Çiçek E., 2004. Effects of peppermint teas on plasma testosterone, follicle-stimulating hormone, luteinizing hormone levels and testicular tissue in rats. Urology 64, 394-98.

Atasu, T., Gezer, A., Erel, T. 2000. Pregnancy and environmental effects. In: Atasü, T. Harmful factors to fetus during gestation and newborn. Nobel Tip Kitapevleri, İstanbul, pp. 477-520.

Baiy, Y., Chen, H., Yuan, ZW., Wang, W., 2004. Normal and abnormal emryonic development of the anorectum in rats. Journal of Pediatric Surgery 39, 587-90.

Balbani, AP, Montovani, JC., 2008. Mobile phones: influence on auditory and vestibular systems. Brazilian Journal of Otorhinolaryngology. 74, 125-31.

Calmihael, SL., Abrams, B. 1997. A critical review of the relationship between gestational 
doi: 10.24998/maensabed.543364

weight gain and preterm delivery. Obstetrics \& Gynecology 89, 865-873.

Chen, CM., Wang, LF., Su, B. 2004. Effects of maternal undernutrition during late gestation on the lung surfactant system and morphometry in rats. Pediatric Research 56, 329-35.

Dipietro, JA., Millet, S., Costigan, KA., Gurewitsch E., Caulfield LE., 2003. Psychosocial influences on weight gain attitudes and behavior during pregnancy. Journal of American Dietetic Association 103, 1314-9.

Ernst, E. 2002. Herbal medicinal products during pregnancy: are they safe?. Britiş Journal of Obstetrics and Gynecology 109, 227-35.

Fan, W., Huang F., Li, C., Qu H., Gao, Z., Leng, S., Li, D., He, H., 2008. Involvement of $\mathrm{NOS} / \mathrm{NO}$ in the development of chronic dental inflammatory pain in rats Brain Research Reviews. 59, 324-32.

Feron, F., Burne, THJ., Brown, J., Smith, E., McGrath, JJ., Mackay-Sim, A., Eyles, DW., 2005. Developmental vitamin D3 deficiency alters adult brain development Brain Research Bulletin 65, 141-8.

Galler, JR., Tonkiss, J., Maldonado-Irizarry, CS. 1994. Prenatal protein malnutrition and home orientation in the rat. Physiology \& Behavior 55, 993-6.

Guney, M., Oral, B., Karahanl1, N., Mungan, T., Akdoan, M., 2006. The effects of Mentha spicata labiatae on uterine tissue in rats. Toxicology and Industrial Health 22, 343-8.

Imai, H., Osawa, K., Yadusa, H., Hamashima, H., Arai, T., Sasatsu M., 2001. Inhibition by the essential oils of peppermint and spearmint of the growth of pathogenic bacteria. Microbios 106, 31-9.

Jamerson, PA., Wulsel, MJ., Kimler, BF. 2004. Neurobehavioral effects in rat pups whose sires were exposed to alcohol. Developmental Brain Research 19, 103-11.

Joshi, S., Garole, V., Daware, M., Girigosiva, S., Rao, S., 2003. Maternal protein restriction before pregnancy affects vital organs of offspring in Wistar rats. Metabolism 52, 13-8.

Lawson, G., Luderer, U. 2004. Gestational and lactional exposure to heptachlor does not after reproductive system development in rats. Veterinary and Human Toxicology 46, 113-8.
Mahajan, SD., Singh, S., Shah, P., Gupta, N., Kochupillai, N., 2004. Effect of maternal malnutrition and anemia on the endocrine regulation of fetal growth. Endocrine Research 30, 189-203.

Malas MA, Dogan S, Evcil EH, Desdicioglu K., 2006. Fetal development of the hand, digits and digit ratio (2D:4D). Early Human Development 82, 469-75.

Moore KL, Persaud TVN., 2002. The Developing Human (Clinically Oriented Embryology). Philadelphia, W.B. Saunders Company, pp. 271-302.

Osgerby, JC., Wathes, DC., Howard, D., Gadd, TS., 2002. The effect of maternal undernutrition on ovine fetal growth. Journal of Endocrinology 173, 131-41.

Saleem, M., Alam, A., Sultana, S. 2000. Attenuation of benzoly peroxide-mediated cutaneous oxidative stress and hyperproliferative response by the prophylactic treatment of mice with spearmint (Mentha spicata). Food and Chemical Toxicology 38(10), 939-48.

Sekiya, N., Anai, T., Matsubara, M., Miyazaki F., 2007. Maternal weight gain rate in the second trimester are associated with birth weight and length of gestation. Gynecologic and Obstetric Investigation 63, 45-48.

Sharp, PE., La Regina, MC. 1998. The Laboratory Rat. CRC Pres LLC. Florida, pp. 1466, 138-156.

Shapiro, C., Sutija, VG., Bush, J. 2000. Effect of maternal weight gain on infant birth weight. Journal of Perinatal Medicine 28(6), 428-31.

Smith, MK., George, EL., Stober, JA., Feng, HLA., Kimmel, GL., 1993. Perinatal toxicity associated with nickel chloride exposure. Environmental Research 61, 200-11.

Torres, SJ., Nowson, CA. 2007. Relationship between stress, eating behavior, and obesity. Nutrition 23, 887-94.

Tyl RW, Chernoff N, Rogers JM., 2007. Altered axial skelatal development. Birth Defects Research Part B: Developmental and reproductive Toxicology 80, 451-72.

Villar, J., Altobelli, L., Kestler, E., Belizan J., 1986. A health priority for developing countries: the prevention of chronic fetal malnutrition. 
Bullettin of the World Health Organization 64, 847-51.

Wells TAG., 1964. The Rat. A Practical Guide, Heinemann Educational Books Ltd, London, pp. 1-77.

Westfall RE., 2004. Use of anti-emetic herbs in pregnancy: women's choices, and the question of safety and efficacy. Complementary Therapies in Nursing and Midwifery 10(1), 30-6

York, RG., Barnett, JJr., Brown, WR., Garman, RH., Mattie, DR., Dodd d., 2004. A rat neurodevelopmental evaluation of offspring including evaluation of adult and neonatal thyroid, from mothers treated with ammonium perchlorate in drinking water. International Journal of Toxicology 23, 191-214.

Zambrano, E., Rodriguez-Gonzalez, GL., Guzman, C., Garcia-Becerra, C., Boeck, L., Daz, L., Menjivar, M., Larrea, F., Nathanielsz, PW., 2005. A maternal low protein diet during pregnancy and lactation in the rat impairs male reproductive development. The Journal of Physiology 15, 275-84

Zhang SW, Bai YZ, Zhang SC, Wang DJ, Zhang T, Zhang D, Wang, WL., 2008. Embryonic development of the striated muscle complex in rats with anorectal malformations. Journal of Pediatric Surgery 43, 1452-8. 